\title{
PENDEKATAN NUMERIK DISIPASI GELOMBANG REGULER OLEH HUTAN MANGROVE MENGGUNAKAN MODEL DISPERSIF BOUSSINESQ
}

\section{NUMERICAL APPROACH OF REGULAR WAVE DISSIPATION BY MANGROVE FOREST USING DISPERSIVE BOUSSINESQ MODEL}

\author{
Didit Adytia* \& Alifa Puspa Yuninda \\ School of Computing, Telkom University, Bandung, 40257, Indonesia \\ *E-mail: adytia@telkomuniversity.ac.id
}

\begin{abstract}
Mangrove forest is one type of coastal forest that forming an ecosystem, in which its root system can dissipate waves, especially for coastal protection. Nevertheless, the effectiveness of mangrove forest for dissipating wave is still unclear, especially for short wave such as regular wave. The purpose of this research is to analyze the effectiveness of mangrove forest in dissipating regular wave by using numerical simulation approach. To simulate short waves accurately, one should choose a dispersive wave model. In this research, we choose a Boussinesq type of model, i.e. the Variational Boussinesq (VB) model as the wave model. Here, the Finite Volume method is chosen as the numerical implementation of model, in a staggered grid scheme. The dissipation process by the mangrove forest is modelled as a bottom dissipation that equivalent with a Manning's coefficient that is derived from physical experiment. The resulting numerical implementation is then validated with experimental data from hydrodynamic laboratory which gives relatively accurate results. To analyze the effectiveness of dissipation by mangrove forest, we perform various simulation scenarios with various length of mangrove forest. From the results, it is shown that to obtain a $67 \%$ wave height dissipation of regular wave, we require at a mangrove forest with length as least 2 times the length incoming regular wave.
\end{abstract}

Keywords: boussinesq, finite volume. mangrove forest, regular wave

\begin{abstract}
ABSTRAK
Hutan mangrove adalah salah satu jenis hutan yang berada di wilayah pesisir dan membentuk sebuah ekosistem, sistem perakaran pada mangrove dapat berfungsi sebagai peredam gelombang terutama untuk proteksi pantai. Namun demikian, efektifitas redaman oleh hutan mangrove masih menjadi pertanyaan, terutama untuk gelombang pendek, seperti gelombang regular. Tujuan dari penelitian ini adalah untuk menganalisis efektifitas dari redaman gelombang regular oleh hutan mangrove melalui pendekatan simulasi numerik. Oleh karena simulasi gelombang pendek memerlukan model gelombang yang bersifat dispersif, pada penelitian ini digunakan model gelombang tipe Boussinesq, yaitu model Variational Boussinesq (VB). Model ini diimplementasikan secara numerik dengan metode Finite Volume pada grid tipe staggered. Proses disipasi oleh hutan mangrove dimodelkan dengan menambahkan suku disipasi pada dasar fluida yang equivalen dengan suatu koefisien Manning yang diturunkan dari eksperimen fisik. Model hasil implementasi numerik ini kemudian divalidasi dengan hasil eksperimen fisik pada laboratorium hidrodinamika, dimana didapatkan hasil cukup baik. Untuk menganalisis efektivitas dari redaman oleh mangrove, dilakukan berbagai skenario simulasi dengan berbagai panjang hutan mangrove. Didapatkan bahwa untuk mendapatkan redaman tinggi gelombang regular sebesar $67 \%$, dibutuhkan paling tidak hutan mangrove dengan panjang 2 kali lipat dari panjang gelombang datang.
\end{abstract}

Kata kunci: boussinesq, finite volume, gelombang reguler, hutan mangrove 


\section{PENDAHULUAN}

Hutan mangrove merupakan salah satu dari ekosistem tumbuhan yang unik, karena selain hidup di lingkungan air payau, ekosistem ini juga memiliki potensi sebagai sumber daya yang alami. Ekosistem hutan mangrove memiliki peran khusus untuk daerah pesisir dikarenakan sistem akar dari tanaman ini dapat melindungi garis pantai, yaitu sebagai pencegahan abrasi yang diakibatkan oleh ombak dengan cara penyerapan energi (disipasi) dan pengurangan kecepatan gelombang (Ismail et al., 2012). Selain mencegah abrasi, ekosistem ini juga memiliki peran penting yang lain, seperti sebagai pemurni air, penyerap polutan, dan mengurangi dampak dari peristiwa ekstrim seperti tsunami (DahdouhGuebas et al., 2005).

Hutan mangrove banyak dijadikan bahan penelitian dimana salah satunya yaitu peran hutan mangrove sebagai media mitigasi yang dapat melindungi garis pantai yang rentan terhadap ombak besar seperti tsunami (Duncan et al., 2016; Kathiresan \& Rajendra, 2005). Struktur batang dan akar dari hutan mangrove yang unik dapat menyerap energi dan mendistribusikannya dengan stabil (Husrin et al., 2012). Penelitian terkait telah menunjukkan bahwa hutan mangrove dapat menyerap energi dari gelombang tsunami, yang mengakibatkan kerusakan pada pemukiman yang berada di belakang hutan mangrove tidak seburuk kerusakan yang terjadi apabila tidak ada hutan mangrove (Strusinska-Correia et al., 2012; Dahdouh et al., 2005; Wolansky, 2006).

Seperti yang diketahui, gelombang merupakan salah satu bagian yang tidak terpisahkan bagi kehidupan disekitar daerah pesisir pantai. Berdasarkan panjang gelombangnya, yang dihitung relatif terhadap kedalaman air, tipe gelombang dapat dibagi menjadi; gelombang panjang $(\lambda / d \geq 20)$, gelombang pertengahan atau intermediate $(20>\lambda / d \geq 1 / 2)$, dan gelombang pendek
$(1 / 2>\lambda / d)$, dimana $\lambda$ menyatakan panjang gelombang, dan $d$ menyatakan kedalaman air. Tsunami biasanya tergolong pada kategori gelombang panjang. Penelitian mengenai dampak redaman gelombang tsunami oleh hutan mangrove telah banyak dilakukan, baik secara eksperimen fisik maupun melalui simulasi numerik (Ismail et al., 2012; Dahdouh-Guebas et al., 2005; Adytia dan Husrin, 2019; Adytia et al., 2019a). Secara numerik, penelitian tentang redaman gelombang oleh hutan mangrove dapat menggunakan model gelombang yang relatif sederhana, yaitu 2 SWE yang valid untuk menyimulasikan gelombang panjang (Adytia et al., 2019a). Pada SWE, variasi kecepatan pada arah vertikal fluida diabaikan. Model ini adalah aproksimasi yang cukup baik dan efisien secara komputasi untuk me-nyimulasikan propagasi gelombang tsunami. Namun demikian, untuk menyimulasikan gelombang pendek dan intermediate, dibutuhkan model gelombang yang bersifat dispersif seperti model gelombang tipe Boussinesq (Adytia et al., 2019b; Lawrence et al., 2018) atau model Non-Hydrostatic (Adytia et al., 2019c). Pada kedua tipe model gelombang ini, variasi kecepatan pada arah vertikal dimodelkan dengan pendekatan tertentu.

Kerusakan garis pantai, selain diakibatkan oleh gelombang panjang seperti tsunami, pada umumnya juga diakibatkan dari hempasan gelombang laut atau wind wave secara terus menerus. Berdasarkan periode dan panjang gelombangnya, jenis gelombang ini termasuk dalam tipe gelombang intermediate dan gelombang pendek, dimana periode gelombang adalah $3 s$ sampai dengan 25s. Secara intensitas, hempasan gelombang laut atau wind wave sangat berkontribusi dalam kerusakan garis pantai. Penelitian mengenai redaman gelombang pendek oleh hutan mangrove masih relatif jarang dilakukan. Pada artikel ini dilakukan studi mengenai redaman gelombang pendek, yaitu gelombang reguler, oleh hutan mangrove. Model gelombang 
yang digunakan adalah model gelombang nonlinier dan bersifat dispersif, tipe Boussinesq yaitu variational Boussinesq (VB) (Adytia et al., 2019b; Lawrence et al., 2018). Model gelombang ini diimplementasikan secara numerik dengan menggunakan metode Finite Volume pada skema staggered grid (Adytia et al., 2019b). Model redaman gelombang oleh hutan mangrove dimodelkan dengan memilih suatu koefisien redaman Manning yang berkorespondensi dengan koefisien drag hutan mangrove (Adytia et al., 2019a). Model numerik yang dibangun kemudian divalidasi dengan menggunakan data eksperimen dari laboratorium hidrodinamika oleh (Husrin et al., 2012). Setelah itu, untuk mempelajari efektifitas dari redaman hutan mangrove dalam meredam gelombang reguler, dilakukan berbagai skenario simulasi numerik untuk berbagai panjang hutan mangrove.

Tujuan dari penelitian ini adalah untuk menganalisis efektifitas redaman gelombang regular oleh hutan mangrove melalui simulasi numerik dengan model dispersif Variational Boussinesq (VB) yang diimplementasikan dengan metode Finite Volume. Dalam menganalisis efektifitas dari redaman, model numerik telah divalidasi dengan data eksperimen laboratorium kemudian digunakan untuk menyimulasikan berbagai skenario simulasi dengan berbagai panjang hutan mangrove.

\section{METODE PENELITIAN}

\subsection{Model Variational Boussinesq}

Simulasi propagasi gelombang yang akurat membutuhkan suatu model matematika gelombang yang akurat serta implementasi numerik yang akurat, stabil, dan efisien secara waktu komputasi. Pada artikel ini, digunakan model gelombang tipe Boussinesq, yang dinamakan model VB yang diimplementasikan secara numerik dengan menggunakan metode Finite Volume pada skema staggered grid.
Model VB merupakan salah satu model tipe Boussinesq yang bersifat nonlinier dan dispersif. Model ini dapat digunakan untuk menyimulasikan gelombang panjang seperti tsunami (Adytia \& Groesen, 2009; Groesen et al., 2008) dan juga gelombang pendek seperti reguler maupun irregular wave (Adytia, 2014; Adytia et al., 2019b; Lawrence et al., 2018). Model VB yang digunakan pada artikel ini adalah model VB dalam 1 dimensi (1D). Model VB diturunkan berdasarkan prinsip variasi gelombang yang diusulkan oleh Luke (1967), dimana air diasumsikan sebagai fluida yang ideal, yaitu fluida yang bersifat tidak kental atau inviscid, tidak termampatkan atau incompressible, dan aliran fluidanya tidak berotasi atau irrotational. Misalkan $x, z$ dan $t$ menyatakan koordinat ruang arah horizontal, vertikal dan waktu. Berdasarkan Luke (1967), dinamika gelombang air dapat dideskripsikan oleh suatu sistem Hamiltonian sebagai berikut:

$\partial_{t} \eta=\delta_{\phi} \mathcal{H}$

$\partial_{t} \phi=-\delta_{\eta} \mathcal{H}$

dimana $\eta(x, t)$ dan $\phi(x, t)$ merupakan variabel kanonik (canonical variables) yaitu elevasi gelombang (surface elevation) dan potensial pada permukaan (surface potential). Notasi $\delta_{\phi} \mathcal{H}$ dan $\delta_{\eta} \mathcal{H}$ menyatakan turunan variasi dari Hamiltonian $\mathcal{H}$ terhadap $\eta$ dan $\phi$. Hamiltonian $\mathcal{H}$ menyatakan total energi, yang merupakan penjumlahan dari energi potensial $\mathcal{P}=\frac{1}{2} \int_{x} g \eta^{2} d x$ dan energi kinetik $\mathcal{K}=\frac{1}{2} \int_{x} \int_{-d}^{\eta}|\nabla \Phi|^{2} d z d x$.

$$
\text { Notasi } \Phi(x, z, t) \quad \text { menyatakan }
$$
potensial fluida, $d$ adalah kedalaman air, dan $g=9,81 \mathrm{~m} / \mathrm{s}^{2}$ adalah percepatan gravitasi. Seperti yang dijelaskan pada Adytia \& Groesen (2012), pada model VB 1D, potensial fluida $\Phi$ pada formula energi kinetik $\mathcal{K}$ diatas dapat dihampiri dengan nilainya pada permukaan $(\phi)$ dan suatu 
kombinasi linier dari fungsi ruang horizontal dan vertikal sebagai berikut:

$$
\begin{aligned}
\Phi(x, z, t) \approx & \phi(x, t)+ \\
& \sum_{m=1}^{M} F^{(m)}(z) \psi^{(m)}(x)
\end{aligned}
$$

dimana $F^{(m)}(z)$ adalah suatu fungsi yang hanya bergantung terhadap ruang vertikal atau yang disebut sebagai profil vertikal, dan $\psi^{(m)}(x, y)$ merupakan suatu variabel bantu yang hanya bergantung terhadap ruang arah horizontal. $M$ menyatakan jumlah kombinasi liniear dari profil vertikal yang dipilih. Untuk $M=2$ atau dua profil vertikal, maka persamaan (3) dapat ditulis menjadi formula sebagai berikut:

$$
\begin{aligned}
\Phi & \approx \phi+F^{(1)} \psi^{(1)}+F^{(2)} \psi^{(2)} \\
& =\phi+\left[\begin{array}{l}
F^{(1)} \\
F^{(2)}
\end{array}\right] \cdot\left[\begin{array}{l}
\psi^{(1)} \\
\psi^{(2)}
\end{array}\right] \ldots \ldots . .
\end{aligned}
$$

Berdasarkan (Adytia et al., 2019b), fungsi profil vertikal $F^{(m)}(z)$ yang dipilih dapat berupa fungsi kosinus hiperbolik yaitu sebagai berikut:

$F^{(m)}(z ; \eta, d)=\frac{\cosh \left(k_{m}(z+d)\right)}{\cosh \left(k_{m} h\right)}-1$

dimana $\kappa_{m}$ adalah bilangan gelombang. Kedalaman fluida total dinyatakan sebagai $h(x, t)=\eta(x, t)+d(x, t)$. Dengan melakukan substitusi hampiran model VB pada (3) kedalaman formula energi kinetik $\mathcal{K}$, maka didapatkan ekspresi energi kinetik untuk model VB $\mathcal{K}_{v}$ yaitu sebagai berikut:

$$
\begin{aligned}
& \mathcal{K}_{v}(\eta, \phi, \psi)= \\
& \frac{1}{2} \int_{x}\left\{\begin{array}{c}
h\left(\partial_{x} \phi\right)^{2}+2 \partial_{x} \phi\left(\begin{array}{c}
\partial_{x} \eta \zeta \cdot \psi+ \\
\beta \cdot \partial_{x} \psi
\end{array}\right)+ \\
{\left[\left(\partial_{x} \eta\right)^{2} \theta+\gamma\right] \psi \cdot \psi+} \\
\alpha \partial_{x} \psi \cdot \partial_{x} \psi+ \\
2 \partial_{x} \eta \epsilon^{\mathrm{T}} \partial_{x} \psi \cdot \psi
\end{array}\right\} d x \cdots(6)
\end{aligned}
$$

Dengan $\alpha, \beta, \gamma, \zeta, \theta$,dan $\epsilon$ merupakan matriks dan vektor koefisien yang diberikan oleh formula berikut ini:

$$
\begin{aligned}
& \alpha^{(i j)}=\int_{-d}^{\eta} F^{(i)} F_{j} d z_{y} \beta^{(j)}=\int_{-d}^{\eta} F^{(j)} d z_{,} \\
& \gamma^{(i j)}=\int_{-d}^{\eta}\left(\partial_{z} F^{(i)}\right)\left(\partial_{z} F^{(j)}\right) d z, \\
& \epsilon^{(i j)}=\int_{-d}^{\eta} F^{(i)} \partial_{\eta} F^{(j)} d z_{p} \\
& \zeta^{(j)}=\int_{-d}^{\eta} \partial_{\eta} F^{(j)} d z_{p} \text { dan } \\
& \theta^{(i j)}=\int_{-d}^{\eta}\left(\partial_{\eta} F^{(i)}\right)\left(\partial_{\eta} F^{(j)}\right) d z .
\end{aligned}
$$

Persamaan model VB dapat diturunkan dengan melakukan substitusi energi kinetik $\mathcal{K}_{v}$ pada persamaan (5) dan energi $\mathcal{P}$ ke dalam persamaan Hamiltonian untuk gelombang air (1) dan (2). Dengan meminimumkan energi kinetik $\mathcal{K}_{v}$ yang pada formula (5) terhadap variabel $\psi$, yaitu dengan melakukan turunan variasi, maka didapatkan sebuah sistem persamaan eliptik (Adytia \& Groesen, 2012; Lawrence et al., 2018).

Persamaan model VB yang didapat dari hasil penurunan persamaan (1) dan (2) adalah persamaan yang ditulis dalam variabel kanonik $\eta$ dan $\phi$. Dalam membuat model ini lebih aplikatif untuk berbagai penerapan pada teknik pantai, maka persamaan tersebut dapat ditulis dalam variabel $\eta$ dan kecepatan horizontal $u(x, t)$. Hal ini dengan memanfaatkan relasi antara potensial permukaan $\phi$ dan kecepatan horizontal $u$ yang diberikan oleh $u=\partial_{x} \phi$. Sistem Hamiltonian yang equivalen dengan (1) dan (2) dalam variabel $u$ adalah sebagai berikut:

$$
\begin{aligned}
& \partial_{t} \eta=-\partial_{x}\left(\delta_{u} \mathcal{H}\right) . . \\
& \partial_{t} u=-\partial_{x}\left(\delta_{\eta} \mathcal{H}\right)
\end{aligned}
$$

dimana $\delta_{u} \mathcal{H}$ adalah turunan variasi dari $\mathcal{H}$ terhadap $u$. Formula energi kinetik dalam variabel $u$ yang ekivalen dengan formula (6) adalah sebagai berikut: 
$K_{v, u}(\eta, u, \psi)=$

$\frac{1}{2} \int_{x}\left\{\begin{array}{c}h u^{2}+2 u\left(\begin{array}{c}\partial_{x} \eta \zeta \cdot \psi+ \\ \beta \cdot \partial_{x} \psi\end{array}\right)+ \\ {\left[\left(\partial_{x} \eta\right)^{2} \theta+\gamma\right] \psi \cdot \psi+} \\ \alpha \partial_{x} \psi \cdot \partial_{x} \psi+ \\ 2 \partial_{x} \eta \epsilon^{T} \partial_{x} \psi \cdot \psi\end{array}\right\} d x$

Dengan menggunakan ekspresi $K_{v, u}(\eta, u, \psi)$ diatas dan ekspresi energi potensial, maka sistem (7) dan (8) dapat ditulis sebagai:

$\partial_{t} \eta=-\partial_{x}\left(h u+\beta \cdot \partial_{x} \psi+\zeta \partial_{x} \eta \cdot \psi\right) \ldots .$.

$\partial_{t} u=-\partial_{x}\left(g \eta+\frac{1}{2} u^{2}+R_{N}\right)-R_{B}$

dimana $R_{N}$ adalah suku nonlinier yaitu sebagai berikut:

$$
\begin{aligned}
R_{N}= & -\partial_{x}(\zeta u \cdot \psi)+u \partial_{x} \eta \zeta_{\eta} \cdot \psi+ \\
& u \beta_{\eta} \cdot \partial_{x} \psi-\partial_{x}\left(\partial_{x} \eta \theta \psi \cdot \psi\right)+ \\
& \frac{1}{2}\left(\partial_{x} \eta\right)^{2} \theta_{\eta} \psi \cdot \psi+\frac{1}{2} \gamma_{\eta} \psi \cdot \psi+ \\
& \frac{1}{2} \alpha_{\eta} \partial_{x} \psi \cdot \partial_{x} \psi-\partial_{x}\left(\epsilon^{T} \partial_{x} \psi \cdot \psi\right)+ \\
& \partial_{x} \eta\left(\epsilon_{\eta}\right)^{T} \partial_{x} \psi \cdot \psi
\end{aligned}
$$

Variabel bantu $\psi$ pada persamaan (10) didapatkan dengan cara meminimisasi formula energi kinetik $K_{v, u}(\eta, u, \psi)$ pada (9) terhadap variabel $\psi$, yang menghasilkan persamaan eliptik sebagai berikut:

$-\partial_{x}\left(\alpha \partial_{x} \psi\right)+\left[\gamma+\left(\partial_{x} \eta\right)^{2} \theta\right] \psi+$ $\partial_{x} \eta \epsilon^{T} \partial_{x} \psi-\partial_{x}\left(\partial_{x} \eta \in \psi\right)=$ $\partial_{x}(\beta u)-\zeta \partial_{x} \eta u$

Dengan $\alpha_{\eta}, \beta_{\eta}, \gamma_{\eta}, \zeta_{\eta}$, dan $\theta_{\eta}$ masingmasing merupakan notasi dari penurunan $\alpha, \beta, \gamma, \zeta$, dan $\theta$ untuk $\eta, \epsilon^{T}$ merupakan transpose dari $\epsilon . R_{B}$ dapat didefinisikan sebagai bottom dissipation yang dapat dituliskan sebagai $R_{B}=\frac{C_{f} u[u]}{h}$, dengan $C_{f}$ merupakan sebuah nilai koefisien dari disipasi oleh dasar fluida (bottom dissipation) yang dapat dituliskan sebagai koefisien Manning $n$ menjadi $C_{f}=\frac{n^{2} g}{h^{1 / \sqrt{8}}}$.

Perhatikan bahwa persamaan (10) adalah persamaan kontinuitas yang merepresentasikan kekekalan massa, sedangkan persamaan (11) adalah persamaan momentum yang merepresentasikan kekekalan momentum, dan persamaan (13) adalah persamaan tambahan yang harus dipecahkan untuk mendapatkan variabel bantu $\psi$. Sistem persamaan (10), (11) dan (13) adalah persamaan nonlinier lengkap (fully nonlinear) model VB dalam variabel $\eta$ dan $u$, lihat Lawrence et al. (2018). Sistem persamaan ini dapat disederhanakan menjadi sistem nonlinier lemah (weakly nonlinear) sehingga lebih ringkas dan efisien secara komputasi, namun tetap akurat (Adytia et al., 2019b). Sistem ini dapat ditulis sebagai berikut:

$$
\begin{aligned}
& \partial_{t} \eta=-\partial_{x}(h u)-\partial_{x}\left(\beta \cdot \partial_{x} \psi\right) \\
& \partial_{t} u=-g \partial_{x} \eta-u \partial_{x} u-R_{B} \ldots \ldots \\
& -\partial_{x}\left(\alpha \partial_{x} \psi\right)+\gamma \psi=\partial_{x}(\beta u) \ldots \ldots
\end{aligned}
$$

Pada subbab berikutnya, sistem (14), (15) dan (16) akan diimplementasikan secara numerik dengan metode Finite Volume pada skema staggered grid.

\subsection{Implementasi Numerik}

Implementasi numerik model VB dengan menggunakan metode Finite Volume pada skema staggered grid diperkenalkan oleh Adytia et al. (2019b) yang terinspirasi oleh metode yang diperkenalkan oleh Stelling \& Duinmeijer (2003). Hasil implementasi model VB dengan metode ini dinamakan Staggered grid Variational Boussinesq (SVB). Ide dari implementasi numerik ini adalah dengan memisahkan grid diskritisasi untuk $\eta, h$ dan $\psi$ yaitu pada grid penuh (full grid), dan grid diskritisasi untuk kecepatan horizontal $u$ pada grid yang berbeda, yaitu grid tengahan (half-grid). 
Ilustrasi penempatan grid ini digambarkan pada Figure 1.

Misalkan domain simulasi didefinisikan pada koordinat horizontal $x \in[0, L]$. Variabel $\eta, d, h, \psi$, dan koefisien $\alpha, \beta, \gamma$ akan didiskritisasi pada full grid yang dapat dinotasikan sebagai $x_{i}, i=1,2, \cdots, N$ dan kecepatan horizontal $u$ pada half grid yang dapat dinotasikan sebagai $x_{i+1 / 2}, i=1,2, \cdots, N+1, \quad$ seperti yang ditunjukkan pada Figure 1.

Dengan digunakannya skema staggered grid, diskritisasi spasial persamaan kontinuitas (13) dan persamaan eliptik (15) dilakukan pada full grid, sedangkan diskritisasi spasial pada persamaan momentum (14) dilakukan pada half grid. Misalkan notasi $\eta_{i}^{n}$ menyatakan $\eta\left(x_{i}, t_{n}\right)$, yaitu elevasi gelombang pada node $x_{i}$ dan pada waktu $t^{n}$, kemudian notasi $u_{i+1 / 2}^{n}$ menyatakan $u\left(x_{i+1 / 2}, t_{n}\right)$, yaitu kecepatan horizontal pada grid tengahan $x_{1+1 / 2}$ dan pada waktu $t^{n}$. Notasi yang sama juga diaplikasikan untuk diskritisasi variabel lainnya. Lebar dari grid spasial dinotasikan sebagai $\Delta x$ dan lebar dari diskritisasi waktu dinotasikan sebagai $\Delta t$.

Pada diskritisasi persamaan kontinuitas (13), turunan spasial dihampiri dengan menggunakan metode central difference (Stelling \& Duinmeijer, 2003), sedangkan turunan temporal dihampiri dengan metode forward difference. Bentuk diskritisasi persamaan (14) dapat ditulis sebagai berikut:

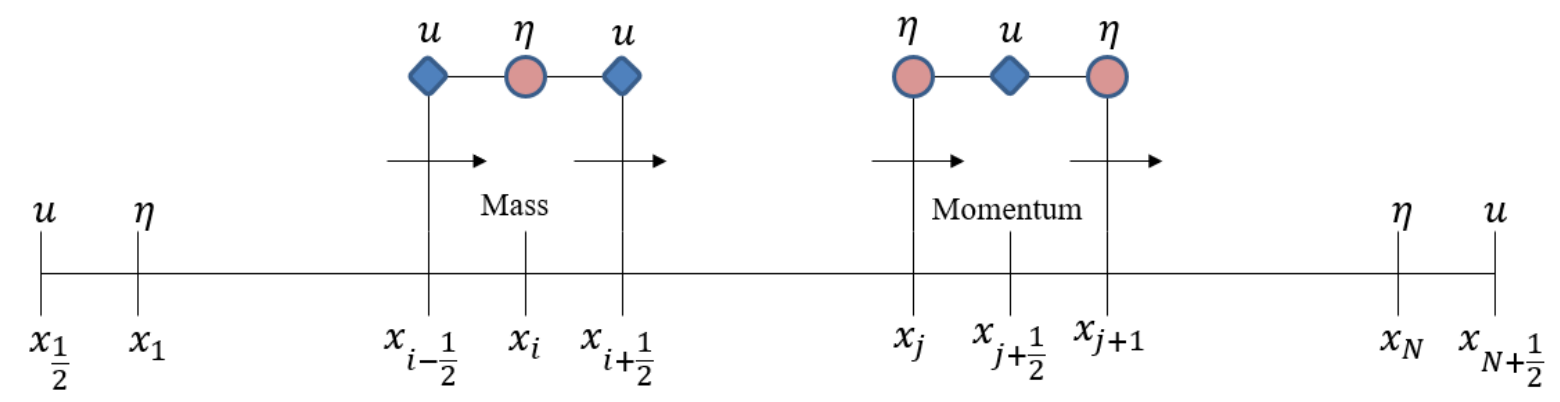

$\frac{\eta_{i}^{n+1}-\eta_{i}^{n}}{\Delta t}=$

$$
\begin{gathered}
-\left(\frac{{ }^{*} h_{i+\frac{1}{2}}^{n} u_{i+\frac{1}{2}}^{n}-{ }^{*} h_{i-\frac{1}{2}}^{n} u_{i-\frac{1}{2}}^{n}}{\Delta x}\right)- \\
\left(\frac{\beta_{i+\frac{1}{2}}^{n}\left(\psi_{i+1}^{n}-\psi_{i}^{n}\right)-\beta_{i-\frac{1}{2}}^{n}\left(\psi_{i}^{n}-\psi_{i-1}^{n}\right)}{(\Delta x)^{2}}\right)
\end{gathered}
$$

Persamaan (17), nilai dari ${ }^{*} h$ pada grid $(i+1 / 2)$ dan $(i-1 / 2)$ dihampiri dengan menggunakan metode upwind yaitu sebagai berikut:

${ }^{*} h_{i+\frac{1}{2}}^{n}=\left\{\begin{array}{l}h_{i}^{n}, \text { jika } u_{i+\frac{1}{2}}^{n} \geq 0 \\ h_{i+1}^{n}, \text { jika } u_{i+\frac{1}{2}}^{n}<0\end{array}\right.$

Formula (18) menyatakan bahwa ketika gelombang bergerak ke arah kanan, yaitu $u_{i+1 / 2}^{n} \geq 0$, maka nilai untuk ${ }^{*} h_{i+1 / 2}^{n}$ didapatkan dari nilai $h$ yang disebelah kiri, yaitu $h_{i}^{n}$. Sebaliknya, jika gelombang bergerak ke arah kiri, atau $u_{i+1 / 2}^{n}<0$, maka nilai ${ }^{*} h_{i+1 / 2}^{n}$ yang digunakan adalah nilai yang disebelah kanan, yaitu $h_{i+1}^{n}$. Dikarenakan koefisien $\alpha, \beta$, and $\gamma$ adalah merupakan fungsi dari $h$, maka analogi yang sama seperti formula upwind pada (18) digunakan untuk mencari nilai ${ }^{*} \alpha,{ }^{*} \beta$, dan ${ }^{*} \gamma$.

Figure 1. Illustration of grid discretization in the domain of computation by using the staggered grid scheme. 
Persamaan momentum model VB (15) didiskritisasi pada half grid, yaitu sebagai berikut:

$$
\begin{aligned}
& u_{i+\frac{1}{2}}^{n+1}=u_{i+\frac{1}{2}}^{n}-g \Delta t\left(\frac{\eta_{i+1}^{n+1}-\eta_{i}^{n+1}}{\Delta x}\right)- \\
& \left(u \partial_{x} u\right)_{i+\frac{1}{a}}^{n}-\left.R_{b}\right|_{i+\frac{1}{a}} ^{n} \cdot
\end{aligned}
$$

dimana suku adveksi $\left(u \partial_{x} u\right)_{i+1 / 2}^{n}$ dihitung dengan menggunakan variabel momentum horizontal $q=h u$ yaitu pada detail penurunan pada Adytia et al. (2019b).

$$
\begin{aligned}
& \left(u \partial_{x} u\right)_{i+\frac{1}{2}}^{n}= \\
& \frac{1}{h_{i+\frac{1}{2}}}\left(\frac{\bar{q}_{i+1}{ }^{*} u_{i+1}-\bar{q}_{i}{ }^{*} u_{i}}{\Delta x}-u_{i+\frac{1}{2}} \frac{\bar{q}_{i+1}-\bar{q}_{i}}{\Delta x}\right) \ldots \ldots . .
\end{aligned}
$$

Tanda bar menyatakan nilai interpolasi variabel-variabel baik pada full grid maupun half grid yang didapat dari nilai rata-rata variabel tersebut pada grid yang tersedia, yaitu sebagai berikut:

$$
\begin{aligned}
& \bar{q}_{i}=\frac{1}{2}\left(q_{i+\frac{1}{2}}+q_{i-\frac{1}{2}}\right), \\
& \bar{h}_{i+\frac{1}{2}}=\frac{1}{2}\left(h_{i+1}+h_{i}\right), \\
& q_{i+\frac{1}{2}}={ }^{*} h_{i+\frac{1}{2}} u_{i+\frac{1}{2}} \cdots . . .
\end{aligned}
$$

Perhatikan bahwa ${ }^{*} u$ belum terdefinisi. Dengan menggunakan analogi seperti pada ${ }^{*} h$, nilai ${ }^{*} u$ dihitung dengan menggunakan skema upwind yaitu sebagai berikut:

$$
{ }^{*} u_{i}^{n}=\left\{\begin{array}{l}
u_{i-1}^{n}, \text { if } \bar{q}_{i}^{n} \geq 0 \\
u_{i+\frac{1}{2}}^{n}, \text { if } \bar{q}_{i}^{n}<0
\end{array}\right.
$$

Suku redaman $R b$ dihitung pada half grid dengan menggunakan:

$\left.R_{b}\right|_{i+\frac{1}{2}} ^{n}=c_{f} \frac{\left|u_{i+1 / 2}^{n}\right| u_{i+1 / 2}^{n+1}}{\hbar_{i+1 / 2}^{n}}$. Perhatikan bahwa

persamaan kontinuitas (14) dan persamaan momentum (15) telah didiskritisasi dalam bentuk skema numerik. Namun nilai $\psi$ pada (17) belum tersedia. Nilai ini didapatkan dengan menyelesaikan persamaan eliptik (16). Bentuk diskritisasi persamaan (16) pada full grid yaitu sebagai berikut:

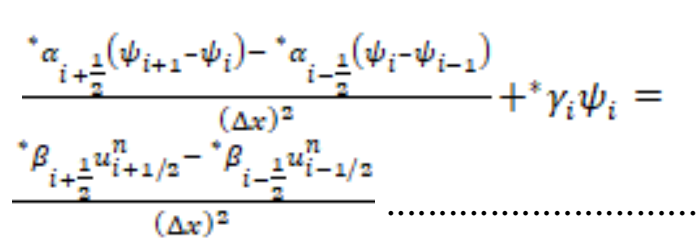

Bentuk skema diskritisasi (23) akan membentuk sistem persamaan matriks linier, dimana untuk nilai $u,{ }^{*} \alpha,{ }^{*} \beta$, dan ${ }^{*} \gamma$ yang diberikan, akan dicari nilai $\psi$. Sistem ini dipecahkan dengan menggunakan algoritma Thomas, untuk setiap langkah waktu (timestep) (Adytia et al., 2019b), untuk penjelasan lebih lanjut. Model VB yang diimplementasikan secara numerik dengan menggunakan skema staggered grid di atas dikenal dengan nama SVB.

\subsection{Eksperimental Fisik Gelombang Reguler}

Eksperimen fisik redaman gelombang reguler oleh hutan mangrove pada laboratorium hidrodinamika dilakukan sebagai bentuk fenomena fisik yang akan dimodelkan secara numerik dimana data hasil eksperimen fisik ini akan digunakan untuk validasi dari model numerik.

Husrin et al. (2012) melakukan eksperimen fisik untuk pengujian redaman gelombang reguler oleh hutan mangrove yang diparameterisasi pada laboratorium hidrodinamika. Eksperimen dilakukan pada Laboratorium TU Braunschweig, LeichwessInstitute, Jerman, pada tangki gelombang (wave tank) kembar, yang berukuran panjang $90 m$, lebar $1 m$ dan $2 m$, serta tinggi $1,2 m$. Pada eksperimen ini dilakukan berbagai skenario jenis gelombang, yaitu gelombang panjang soliter yang merepresentasikan gelombang tsunami, gelombang pendek atau reguler dan gelombang acak (irregular wave). Eksperimen fisik ini dilakukan 
bertujuan untuk menganalisis redaman berbagai tipe gelombang oleh hutan mangrove yang diparameterisasi, untuk merekonstruksi prosedur standar parameterisasi hutan mangrove dan kemudian menurunkan koefisien $\operatorname{drag} C_{D}$ dan koefisien inersia $C_{M}$ yang merepresentasikan redaman hutan mangrove tersebut.

Pada eksperimen ini, hutan mangrove direpresentasikan dalam bentuk ideal yang diparameterisasi (parameterized model) dengan menggunakan rangkaian batang silinder. Pada kolam gelombang dengan lebar $2 m$, dipasang rangkaian model hutan mangrove dimana masing-masing model hutan mangrove tersebut mempunyai lebar $15 \mathrm{~cm}$, yang tersusun dari batang (trunk) dengan diameter silinder $1,0 \mathrm{~cm}$ dan tinggi $61,5 \mathrm{~cm}$, dan akar-akar (roots) dengan diameter silinder $0,5 \mathrm{~cm}$ dan tinggi yang bervariasi 43,5-51,5cm membentuk piramida. Masing-masing dari model hutan mangrove ini disusun dalam bentuk yang bersilang (staggered) sehingga pada lebar kolom gelombang terdiri dari 12 atau 13 model dalam 1 baris. Pada eksperimen dengan model hutan mangrove dengan panjang $B=$ $0,75 \mathrm{~m}$, terdiri dari 62 model hutan mangrove, untuk $B=1,50 m$ terdiri dari 125 model hutan mangrove, dan $B=3,00 \mathrm{~m}$ dengan 250 model hutan mangrove. Kepadatan dari hutan mangrove pada eksperimen ini adalah $N_{s}=$ 0,066 pohon $/ \mathrm{m}^{2}$. Selain itu, pada eksperimen ini hutan mangrove hanya terendam sebagian yaitu pada kedalaman $0,2 m$ (Husrin et al. 2012).
Eksperimen dengan hutan mangrove dilakukan pada tangki dengan lebar $2 \mathrm{~m}$, sedangkan tangki dengan lebar $1 m$ tanpa hutan mangrove. Pada tengah tangki dipasang profil dasar air dengan kemiringan 1:20, dari kedalaman $d_{0}=0,625 \mathrm{~m}$ sampai dengan kedalaman $d_{l}=0,2 m$, yang merepresentasikan skala 1:25. Ilustrasi konfigurasi eksperimen fisik yang dilakukan ditunjukkan pada Figure 2. Terdapat total 50 buah alat pengukur elevasi gelombang maupun pengukur kecepatan yang dipasang pada tangki gelombang. Jenis eksperimen gelombang reguler yang digunakan pada artikel ini adalah eksperimen nomor 2009051305, dengan tinggi gelombang $0,16 m$ dengan periode gelombang $2,2 s$ atau pada dimensi fisik yang sebenarnya merepresentasikan gelombang dengan tinggi $4 m$ dengan periode $11 s$.

\subsection{Pemodelan Disipasi Gelombang oleh Vegetasi}

Proses disipasi gelombang oleh vegetasi, termasuk hutan mangrove, dapat dimodelkan dengan formulasi klasik yang diperkenalkan oleh Morison et al. (1950), dimana gaya total oleh vegetasi dapat ditulis sebagai berikut:

$F_{\text {tot }}=\frac{1}{2} C_{D} \rho A_{f} u^{2}+C_{M} \rho V \partial_{t} u$.

dimana $F_{\text {tot }}$ adalah gaya total disipasi oleh gaya drag (drag force) dan gaya inersia

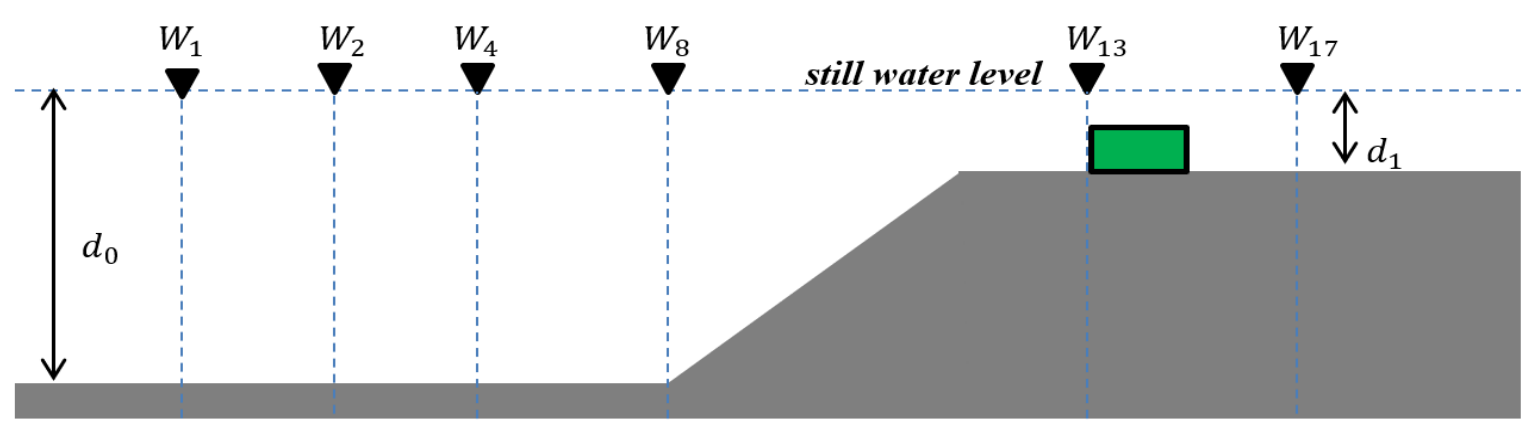

Figure 2. Configuration of the physical experiment. Black rectangle denotes the position and length of the mangrove forest. 
(inertia force). Gaya drag diekspresikan oleh suku pertama pada formula (24), yang terdiri dari koefisien $\operatorname{drag} C_{D}$, massa jenis air $\rho, A_{f}$ yang merepresentasikan luas dari vegetasi, dan $u$ adalah kecepatan horizontal. Suku kedua pada (24) merepresentasikan gaya inersia, yang terdiri dari koefisien inersia $C_{M}$, volume dari vegetasi yang terendam pada fluida $V$, dan turunan kecepatan horizontal terhadap waktu $\partial_{t} u$. Koefisien drag maupun inersia biasanya diturunkan secara empirik dari percobaan pada laboratorium hidrodinamika. Gaya total $F_{\text {tot }}$ dapat diimplementasikan ke dalam persamaan momentum. Penerapan gaya ini pada model Nonhydrostatic (Adytia et al., 2019c).

Pada artikel ini, mekanisme disipasi gelombang oleh vegetasi dimodelkan melalui suku redaman oleh dasar fluida (bottom roughness) yaitu melalui suatu koefisien Manning $n$ yang berkorelasi dengan gaya drag dan gaya inersia. Relasi ini diperkenalkan oleh Yanagisawa et al. (2009), yaitu sebagai berikut:

$$
n_{v}=\sqrt{\frac{h^{4 / s}}{2 g V}\left(C_{D} A_{f}\right)+n_{b}}
$$

dimana $n_{v}$ adalah koefisien Manning yang berkorelasi dengan disipasi oleh vegetasi, sedangkan $n_{b}$ adalah koefisien Manning yang terkait dengan kekasaran dari dasar fluida (bottom roughness).

Rekonstruksi ulang eksperimen disipasi gelombang reguler oleh hutan mangrove yang dilakukan oleh Husrin et al. (2012) pada artikel ini menggunakan koefisien Manning $n_{v}=0,13$, yang diturunkan dari koefisien drag pada eksperimen redaman gelombang oleh hutan mangrove.

\section{HASIL DAN PEMBAHASAN}

Penelitian yang membahas tentang efektifitas redaman gelombang reguler, yang termasuk dalam gelombang pendek, oleh hutan mangrove termasuk masih sangat sedikit. Penelitian tentang redaman hutan mangrove pada umumnya diperuntukkan hanya untuk gelombang panjang, misalnya gelombang soliter, yang digunakan untuk menghampiri bentuk dari gelombang tsunami. Sihombing (2018) melakukan studi numerik dengan model CFD yang berdasarkan model 3D Navier-Stokes (RANS) untuk mempelajari redaman dari gelombang soliter terhadap hutan mangrove pada dasar air yang rata, berdasarkan eksperimen Huang et al. (2011). Untuk data eksperimen yang sama yaitu Huang et al. (2011), Adytia et al. (2019d) menggunakan model gelombang jenis Non-Hydrostatic untuk merekonstruksi redaman gelombang soliter oleh hutan mangrove pada dasar rata. Pada artikel ini, redaman oleh hutan mangrove yang dipelajari adalah dengan konfigurasi tipe topografi yang tidak rata dan jenis gelombang yang dipelajari adalah gelombang reguler yang tergolong gelombang pendek.

\subsection{Validasi Model Numerik}

Eksperimen redaman gelombang reguler oleh hutan mangrove oleh Husrin et al. (2012), yang direkonstruksi pada artikel ini adalah eksperimen dengan nomor 2009051305. Pada eksperimen ini gelombang reguler dibangkitkan pada bagian sebelah kiri tangki gelombang oleh pembangkit gelombang pada dasar rata dengan kedalaman air $d_{0}=0,625 \mathrm{~m}$ dan $d_{1}=0,2 \mathrm{~m}$, seperti yang diilustrasikan pada Figure 2. Tinggi gelombang reguler yang dibangkitkan adalah $0,16 m$ dengan periode gelombang $2,2 s$. Dengan menggunakan skala 1:25, dimensi fisik gelombang yang dibangkitkan merepresentasikan gelombang dengan tinggi $4 m$ dengan periode $11 s$ pada kedalaman $15 \mathrm{~m}$. Dimensi gelombang ini cukup merepresentasikan keadaan gelombang pada saat terjadi gelombang tinggi.

Pada eksperimen 2009051305, panjang hutan mangrove yang dipasang pada tangki gelombang adalah $B=0,75 \mathrm{~m}$ atau dalam dimensi geofisiknya merepresentasi- 
kan hutan mangrove dengan panjang $18 \mathrm{~m}$. Berdasarkan Husrin et al. (2012), digunakan koefisien Manning yang merepresentasikan hutan mangrove $n_{v}=0,13$. Untuk merekontruksi eksperimen di atas, digunakan domain komputasi $x \in[-10 \mathrm{~m}, 60 \mathrm{~m}]$, yang didiskritisasi dengan lebar partisi spasial $\Delta x$ $=0,1 \mathrm{~s}$, dan diskritisasi terhadap waktu $\Delta t=$ $0,02 s$. Gelombang dibangkitkan dengan metode embedded influxing seperti pada Adytia et al. (2019b), pada posisi wave gauge $W_{1}$ pada $x=10 \mathrm{~m}$. Pada metode embedded influxing, gelombang yang akan disimulasikan, dibangkitkan di dalam domain komputasi dengan cara menambahkan sebuah suku pembangkit atau source term pada persamaan kontinuitas gelombang. Pada artikel ini, pembangkitan gelombang dipilih pada posisi $W_{1} \quad(x=10 \mathrm{~m})$ dikarenakan merupakan posisi wave gauge terdekat dari pembangkit gelombang atau wave flap yang terletak pada $x=0$. Sinyal gelombang pada posisi $W_{1}$ ditunjukkan pada bagian atas Figure 3.

Rekonstruksi simulasi gelombang dilakukan dengan menambahkan peredam gelombang atau wave damper pada kedua sisi domain untuk meredam gelombang,

Sinyal pada $\mathrm{x}=\mathrm{W}_{1}$
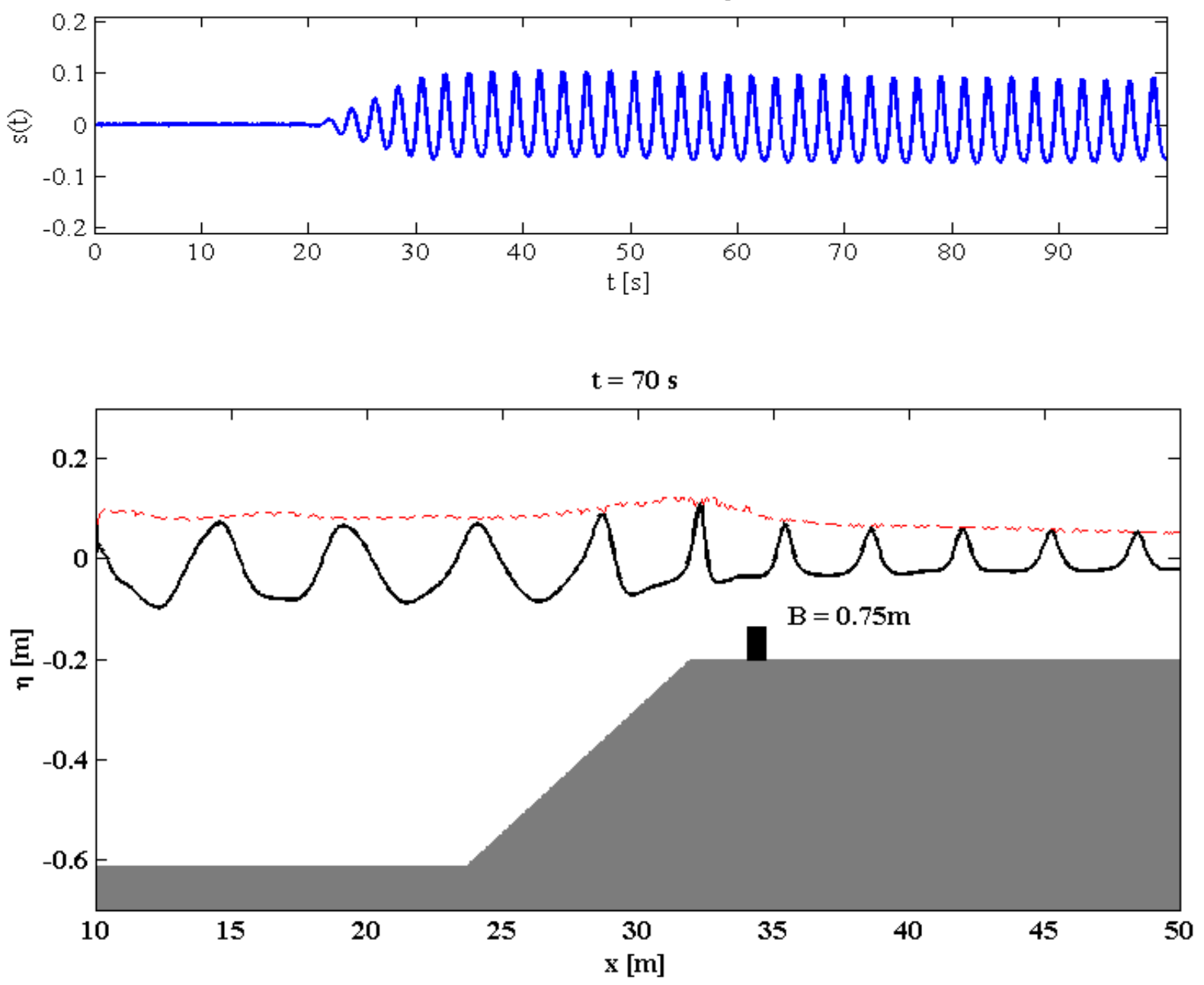

Figure 3. In the top plot is the wave signal at position $W_{1}$. In the lower plot is results of simulation by using $S V B$ (solid black line) at $t=70 \mathrm{~s}$. Black rectangle indicates the location of mangrove forest location, with length of $B=0.75 \mathrm{~m}$, and the red dashed line denotes the maximum waveheight. 
sepanjang masing-masing $10 \mathrm{~m}$. Simulasi dilakukan selama $100 s$, dengan periode gelombang reguler $T=2,2 s$, maka terdapat kurang lebih 40 gelombang harmonik yang dibangkitkan dan berpropagasi didalam tangki gelombang. Hasil simulasi dengan menggunakan model SVB pada waktu $t=70 \mathrm{~s}$ ditunjukkan pada Figure 3 pada bagian bawah. Terlihat dari Figure 3 bagian bawah bahwa gelombang mengalami penurunan, yaitu pecah, sebelum menabrak hutan mangrove yang mempunyai panjang $B$ $=0,75 \mathrm{~m}$. Hasil simulasi numerik divalidasi dengan sinyal hasil pengukuran dari eksperimen fisik, yaitu pada posisi sebelum hutan mangrove yaitu $W_{4}(x=12,225 m), W_{5}$ $(x=21,415 m), W_{8}(x=23,65 m)$ dan pada posisi sesudah hutan mangrove yaitu $W_{17}$ ( $x$ $=37,01 \mathrm{~m})$. Perbandingan ini ditunjukkan pada Figure 4. Dari hasil perbandingan kualitatif pada Figure 4, terlihat bahwa model numerik dapat merekonstruksi eksperimen, bahkan pada posisi setelah hutan mangrove, yaitu pada $W_{17}$. Dari simulasi tersebut, terlihat bahwa tinggi gelombang mengalami penurunan yang cukup signifikan pada $W_{4}-W_{8}$ menjadi pada posisi $W_{17}$. Namun demikian, model numerik masih dapat merepresentasikan hasil eksperimen fisik secara relatif akurat.
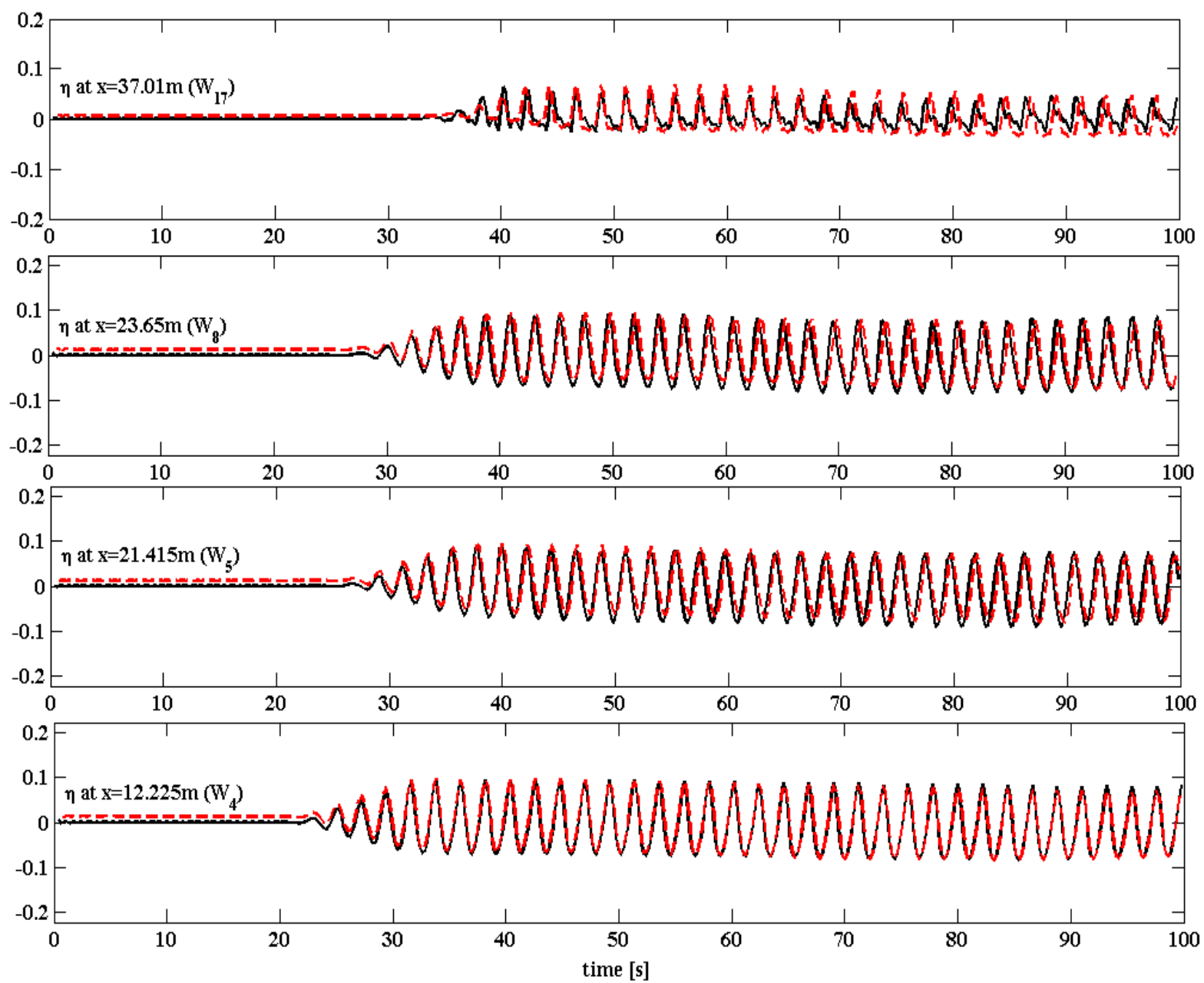

Figure 4. Comparison of signal between results of the numerical simulation (dashed line) with observation data (solid black line) at position $W_{4}(x=12.225 \mathrm{~m})$, $W_{5}(x=21.415 \mathrm{~m}), \quad W_{8}(x=23.65 \mathrm{~m})$ and at after the mangrove forest $W_{17}(x=37.01 \mathrm{~m})$. 
Pendekatan Numerik Disipasi Gelombang Reguler oleh Hutan Mangrove ...

Table 1. RMSE and CorrCoef values at several wave gauge positions.

\begin{tabular}{lcccc}
\hline Position $(m)$ & 12.225 & 21.415 & 23.65 & 37.01 \\
\hline RMSE $(\mathrm{m})$ & 0.0105 & 0.0269 & 0.0306 & 0.0204 \\
CorrCoeff & 0.97675 & 0.83184 & 0.77212 & 0.55077 \\
\hline
\end{tabular}

Perbandingan kuantitatif antara hasil simulasi dan data experimen dibandingkan dengan menghitung nilai Relative Mean Square Error (RMSE) dan Koefisien Korelasi (CorrCoeff) antara kedua sinyal yang dibandingkan. Formula dari RMSE dan CorrCoeff didefinisikan sebagai berikut:

$R M S E=\sqrt{\frac{\left(\Sigma_{i=1}^{N}\left(y_{i}-\hat{\gamma}_{i}\right)\right.}{N}}$, dan

$\operatorname{CorrCoeff}(y, \hat{y})=\frac{\langle y \hat{y}>}{\|y\||\hat{y}|}$

dimana $y$ merupakan sinyal dari hasil eksperimen dan $\hat{y}$ adalah sinyal dari hasil simulasi. Notasi |.| menunjukkan norm $L_{2}$

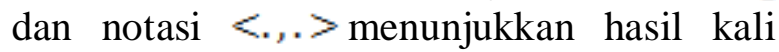
dalam atau inner product. Nilai RMSE yang semakin kecil menunjukkan bahwa hasil simulasi yang mendekati hasil eksperimen. Nilai CorrCoef terdefinisi pada $[0,1]$ dimana, CorrCoef $=1$ menunjukkan kedua data yang sangat berkorelasi. Hasil perbandingan antara hasil simulasi numerik dan eksperimen pada lokasi $W_{4}(x=12,225 m), W_{5}(x=$ $21,415 m), W_{8}(x=23,65 m)$ dan pada posisi sesudah hutan mangrove yaitu $W_{17}(x=$ $37,01 \mathrm{~m}$ ) diperlihatkan pada Table 1 . Pada Table 1, terlihat bahwa nilai RMSE pada lokasi setelah hutan mangrove yaitu pada $W_{17}$ $(x=37,01 m)$ masih relatif sangat kecil, yaitu $0,0204 \mathrm{~m}$. Nilai CorrCoef mengalami penurunan yaitu menjadi hanya 0,55 di lokasi setelah hutan mangrove $\left(W_{17}\right)$. Nilai CorrCoef menyatakan besar beda fase antara sinyal hasil simulasi dan hasil eksperimen, sedangkan nilai RMSE mengindikasikan besaran galat atau eror pada kedua tinggi gelombang dari sinyal yang dibandingkan. Hasil pada Table 1 menunjukkan bahwa hasil simulasi numerik dapat memprediksi tinggi gelombang relatif cukup akurat jika dibandingkan dengan hasil eksperimen.

\subsection{Simulasi dengan Berbagai Panjang Hutan Mangrove}

Pada bagian ini, model numerik yang telah divalidasi pada bagian sebelumnya, akan digunakan untuk menyimulasikan berbagai panjang hutan mangrove. Dengan menggunakan konfigurasi numerik seperti pada kasus eksperimen 2009051305, dilakukan skenario simulasi dengan panjang hutan mangrove $B=3 ; 6$; dan $12 \mathrm{~m}$. Skenario ini dilakukan untuk melihat efektifitas redaman hutan mangrove terhadap gelombang reguler.

Hasil simulasi numerik dengan model SVB untuk panjang hutan mangrove $B=12 m$ ditunjukkan pada Figure 5. Seperti pada gambar, terlihat bahwa tinggi gelombang mengalami penurunan secara signifikan ketika gelombang melintasi hutan mangrove. Tinggi penurunannya tinggi gelombang adalah dari $0,1084 m$ menjadi $0,0223 m$, atau terjadi penurunan sebesar 79\%. Panjang gelombang reguler untuk kasus eksperimen 2009051305 pada daerah dangkal $\left(d_{1}=0,2 m\right)$ sebelum memasuki hutan mangrove adalah $\lambda=2 \mathrm{~m}$, sehingga untuk panjang hutan mangrove $B=12 \mathrm{~m}$ (atau 6 $\lambda$ ), terjadi penurunan tinggi gelombang sebesar 79\%.

Simulasi gelombang untuk skenario panjang hutan mangrove lainnya, yaitu $B=$ 0,$75 ; 3 ; 6$ dan $12 m$, hasil redaman gelombang yang dihasilkan ditunjukkan pada Figure 6. Hasil disipasi tinggi gelombang untuk berbagai skenario panjang hutan mangrove ini dirangkum pada Table 2. Pada Table 2, $A_{0}$ menyatakan tinggi gelombang sebelum mengenai hutan mangrove, yaitu pada $x=34 \mathrm{~m}$, sedangkan $A_{1}$ menyatakan tinggi 
gelombang sesudah melewati hutan mangrove, yang diukur $1 m$ setelah ujung kanan hutan mangrove. Terlihat bahwa untuk panjang hutan mangrove $\mathrm{B}=0,75 \mathrm{~m}$, disipasi tinggi gelombang yang dihasilkan adalah $24,81 \%$, sedang untuk $B=6 m$, disipasi yang dicapai adalah $67 \%$.
Table 2. Wave dissipation with various mangrove forest length $B$.

\begin{tabular}{cccc}
\hline $\boldsymbol{A}_{\mathbf{0}}[\mathrm{m}]$ & $B[\mathrm{~m}]$ & $\boldsymbol{A}_{\mathbf{1}}[\mathrm{m}]$ & Dissipation $[\%]$ \\
\hline 0.1048 & 0.75 & 0.0788 & 24.81 \\
0.1048 & 3.00 & 0.0485 & 53.72 \\
0.1048 & 6.00 & 0.0340 & 67.56 \\
0.1048 & 12.00 & 0.0214 & 79.60 \\
\hline
\end{tabular}

$\mathrm{t}=70 \mathrm{~s}$

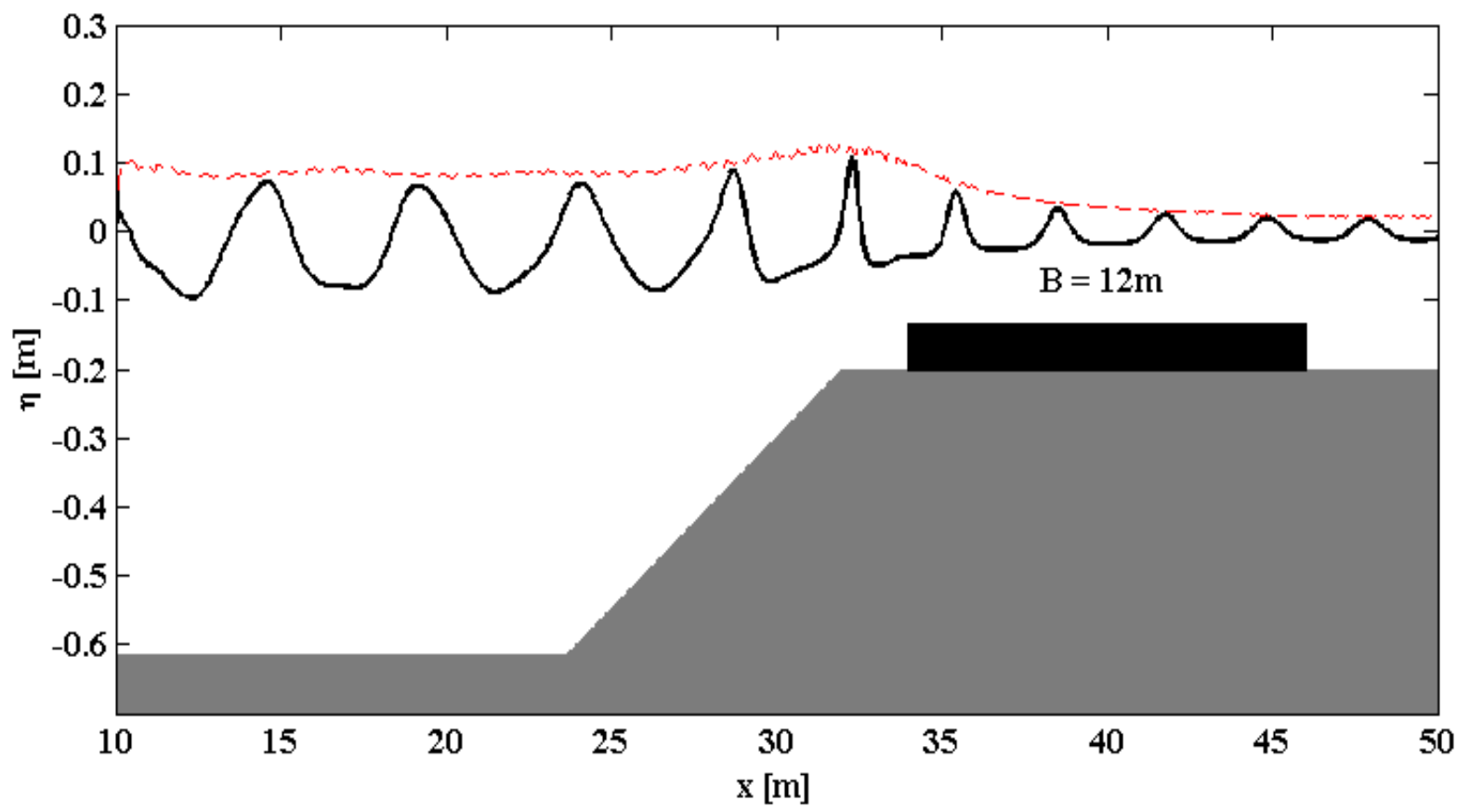

Figure 5. Results of numerical simulation (solid black line) at time $t=70$ s for the scenario with length of mangrove forest $B=12 \mathrm{~m}$.
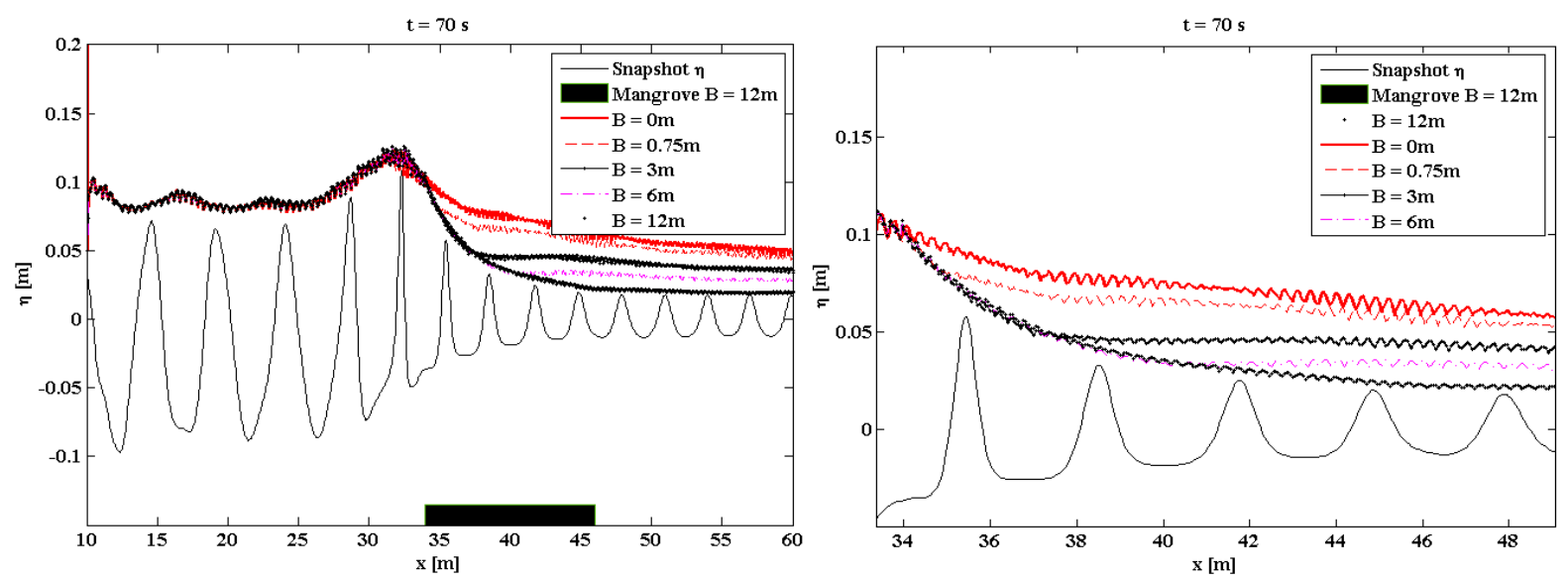

Figure 6. Maximum waveheight for several scenarios with various length of mangrove forest, i.e. $B=0,0.75,3,6$ dan $12 \mathrm{~m}$. In the right plot is the zoom view in the dissipation area. 


\section{KESIMPULAN}

Hasil simulasi dengan menggunakan model dispersif variational Boussinesq untuk berbagai skenario panjang hutan mangrove menunjukkan bahwa panjang hutan mangrove sangat mempengaruhi efektifitas dari disipasi gelombang data. Untuk simulasi gelombang dengan panjang hutan mangrove $B=0,75 m ; 3 m ; 6 m$ dan $12 m$, didapatkan disipasi gelombang sebesar 24\%, 53\%, $67 \%$ dan $79 \%$. Hal ini menunjukkan bahwa terdapat relasi nonlinear antara panjang hutan mangrove dan besar disipasi gelombang regular. Secara umum dapat disimpulkan bahwa semakin panjang hutan mangrove, maka semakin besar disipasi gelombang yang didapatkan. Namun demikian, untuk mendisipasikan gelombang 100\%, dibutuhkan panjang hutan mangrove yang relatif sangat panjang, yaitu lebih dari 4 kali panjang gelombang datang.

\section{UCAPAN TERIMA KASIH}

Penulis berterima kasih kepada Dr. Semeidi Husrin dan Leichtweiss Institute (LWT)-TU Braunschweig-Jerman yang telah memberikan data eksperimen.

\section{DAFTAR PUSTAKA}

Adytia, D., D. Tarwidi, S.A. Kifli, \& S.R. Pudjaprasetya. 2018. Staggered grid implementation of 1D Boussinesq model for simulating dispersive wave. IOP J. of Physics: Conf. Series, 971(1): 1-7.

http://doi.org/10.1088/17426596/971/1/012020

Adytia, D. \& E. van Groesen. 2012. Optimized variational 1D boussinesq modelling of coastal wave propagation over a slope. Coastal Engineering, 64(12): 139-150. https://doi.org/10.1016/j.coastaleng.2 012.02 .001
Adytia, D., S. Husrin, \& A.L. Latifah. 2019a. Dissipation of solitary wave due to mangrove forest: a numerical study by using non-dispersive wave model. Indonesian J. of Marine Sciences, 24(1): 41-50. http://doi.org/10.14710/ik.ijms.24.1.4 $1-50$

Adytia, D., S.R. Pudjaprasetya, \& D. Tarwidi. 2019b. Modeling of wave run-up by using staggered grid scheme implementation in 1D Boussinesq model. Computational Geosciences, 23(4): 793-811. https://doi.org/10.1007/s10596-0199821-5

Adytia, D., D. Tarwidi, \& A.P.A, Hadna. 2019c. Momentum conservative scheme for simulating wave runup and underwater landslide. Indonesian J. on Computing, 4(1): 29-41. http://doi.org/10.21108/indojc.2019.4. 1.250

Adytia, D., M.A. Fadhilah, \& S.R. Pudjaprasetya. 2019d. Numerical simulation of solitary wave attenuation by vegetation with nonhydrostatic model. IOP J. of Physics: Conference Series, 1192(1): 1-7. http://doi.org/10.1088/17426596/1192/1/012039

Dahdouh-Guebas, F., L.P. Jayatissa, D. Di Nitto, J.O. Bosire, D. Lo Seen, \& N. Koedam. 2005. How effective were mangroves as a defence against the recent tsunami?. Current Biology, 15(12): 443-447. https://doi.org/10.1016/j.cub.2005.06. 008

Duncan, C., J.H. Primavera, N. Pettorelli, J.R. Thomson, R.J.A., Loma, \& H.J. Koldewey. 2016. Rehabilitating mangrove ecosystem services: A case Study on the relative benefits of abandoned pond reversion from Panay Island, Philippines. Marine Pollution Bulletin, 109: 772-782. 
Groesen, van E., D. Adytia, \& Andonowati. 2008. Near-coast tsunami waveguiding: phenomenon and simulations. National Hazards Earth System Science, 8(2): 175-185. https://doi.org/10.5194/nhess-8-1752008

Husrin, S., A. Strusinka, \& H. Oumeraci. 2012. Experimental study on tsunami attenuation by mangrove forest. Earth Planets Space, 64(10): 973-989. http://doi.org/10.5047/eps.2011.11.00 8

Huang, Z., Y. Yao, S.Y. Sim, \& Y. Yao. 2011. Interaction of solitary waves with emergent, rigid vegetation. Ocean Engineering, 38(10): 1-8. https://doi.org/10.1016/j.oceaneng.20 11.03.003

Ismail, H., A.K. Abd Wahab, \& N.E, Alias. 2012. Determination of mangrove forest performance in reducing tsunami run-up using physical models. Natural Hazards, 63(2): 939963. https://doi.org/10.1007/s11069012-0200-y

Kathiresan, K. \& N. Rajendran. 2005. Coastal mangrove forests mitigated tsunami. Estuarine, Coastal and Shelf Science, 65(3): 601-606.

https://doi.org/10.1016/j.ecss.2005.06 .022

Luke, J. 1967. A variational principle for a fluid with a free surface. J. of Fluid Mechanics, 27(2): 395-397.

https://doi.org/10.1017/S0022112067 000412

Lawrence, C., D. Adytia, \& E. van Groesen. 2018. Variational boussinesq model for strongly nonlinear dispersive waves. Wave motion, 76: 78-102. https://doi.org/10.1016/j.wavemoti.20 17.10.009

Morison, J.R., J.W. Johnson, \& S.A. Schaaf. 1950. The force exerted by surface waves on piles. J. of Petroleum
Technology, 2(05): 149-154. https://doi.org/10.2118/950149-G

Sihombing. 2018. Transformasi gelombang soliter oleh fleksibilitas vegetasi pantai. J. Teknik Sipil, 14(1): 1-103. https://doi.org/10.28932/jts.v14i1.144 9

Stelling, G.S. \& S.A. Duinmeijer. 2003. A staggered conservative scheme for every froude number in rapidly varied shallow water flows. International Journal for numerical methods in fluids, 43(12): 1329-1354. https://doi.org/10.1002/fld.537

Strusinska-Correia, A., S. Husrin, \& H. Oumeraci. 2012. Tsunami damping by mangrove forest: a laboratory study using parameterized trees. Natural Hazards Earth System Science, 13: 483-503. http://doi.org/10.5194/nhess-13-4832013

Wolansky, E. 2006. Thematic paper: Synthesis of the protective functions of coastal forests and trees against natural hazards. In: Braatz, S. et al. (ed.). Coastal protection in the aftermath of the Indian Ocean Tsunami. FAO Regional Office for Asia and The Pacific. Chapter 6:161$184 \mathrm{pp}$.

Yanagisawa, H., S. Koshimura, K. Goto, T. Miyagi, F. Imamura, A. Ruangrassamee, \& C. Tanavud. 2009. The reduction effects of mangrove forest on a tsunami based on field surveys at Pakarang Cape, Thailand and numerical analysis. Estuarine, Coastal and Shelf Science, 81(1): 2737.

https://doi.org/10.1016/j.ecss.2008.10 .001

$\begin{array}{ll}\text { Received } & : \text { 12 June } 2019 \\ \text { Reviewed } & : \text { 30 September } 2019 \\ \text { Accepted } & : \text { :02 April } 2020\end{array}$


